\title{
RASIONALITAS PENGGUNAAN OBAT TUBERKULOSIS PARU DI PUSKESMAS PANGKALAN SUSU KABUPATEN LANGKAT SUMATERA UTARA
}

\author{
Zulfikri', Nur Ainun ${ }^{2 *}$ \\ ${ }^{1,2}$ Program Studi Farmasi, Fakultas Ilmu Kesehatan, Universitas Haji Sumatera Utara \\ Medan, Indonesia \\ Email: inunarsyad12@gmail.com \\ * corresponding author
}

\begin{abstract}
Abstrak
Tuberkulosis adalah penyakit menular yang disebabkan oleh Mycobacterium Tuberculosis. Penyakit TB masih menjadi permasalahan utama dalan bidang kesehatan terutama di Indonesia. Keberhasilan pengobatan TB sangatlah penting untuk mengurangi penularan penyakit dan kematian pasien TB. Salah satu faktor yang mempengaruhi keberhasilan pengobatan yaitu penggunaan obat yang rasional. Penelitian ini bertujuan untuk mengetahui apakah pemakaian obat TB di Puskesmas Pangkalan Susu Kecamatan Pangkalan Susu Kabupaten Langkat Sumatera Utara sudah rasional atau belum. Penelitian ini dilakukan dengan metode pengambilan data dari rekam medis pasien TB paru di Puskesmas Pangkalan Susu. Total sampel 24 orang pasien TB paru selama tahun 2019.Hasil penelitian menunjukkan bahwa ketepatan penggunaan obat Anti Tuberkulosis di Puskesmas Pangkalan Susu Kecamatan Pangkalan Susu Kabupaten Langkat Sumatera Utara pada periode 2019 yaitu tepat indikasi 100\%, tepat pasien 100\%, tepat pemilihan obat $100 \%$, tepat lama pemakaian obat $95,83 \%$ dan tepat dosis $100 \%$.
\end{abstract}

Kata kunci: Tuberkulosis, Obat Anti Tuberkulosis, Pasien TB, Rasional

\begin{abstract}
Tuberculosis is an infectious disease which is caused by Mycobacterium tuberculosis. Tuberculosis diaseas is still a major problem in the health sector,especially in Indonesia. The success of TB treatment is essential to reduce the transmission of TB diseases and deaths. One of the factors that influence the success of treatmentis the rational use of drugs. This study aims to determine whether the use of TB drugs in Pangkalan Susu Puskesmas, Pangkalan Susu, Langkat Regency, North Sumatra is rational or not. This research was conducted methode by collecting data from the medical records of pulmonary TB patients at Pangkalan Susu Puskesmas . A total sample of 24 pulmonary tuberculosis patients during 2019. The results showed that the accuracy of using anti-tuberculosis drugs at Pangkalan Susu Pangkalan Susu, Pangkalan Susu District Langkat Regency, North Sumatra in the 2019 period was 100\% correct indication, 100\% right patient, 100\% correct drug selection, $95.83 \%$ correct duration of drug use and appropriate dosage $100 \%$.
\end{abstract}

Keywords: Tuberculosis, Anti-Tuberculosis Drugs, TB Patients, Rational 


\section{Pendahuluan}

Tuberkulosis adalah penyakit menular langsung yang disebabkan oleh kuman TB (Mycobacterium tuberculosis). Sebagian besar kuman TB menyerang paru, tetapi dapat juga mengenai organ tubuh lainnya. Salah satu penyakit penyebab kematian utama yang disebabkan oleh infeksi adalah tuberculosis (TB), sebanyak seperempat juta orang bertambah penderita baru dan sekitar 140.000 kematian tiap tahunnya (Binfar RI ,2005).TB paru dapat disembuhkan dengan pengobatan yang tepat dan sesuai dengan panduan pengobatan tuberkulosis. Pengobatan bertujuan untuk menyembuhkan, meningkatkan kualitas hidup dan produktivitas pasien, mencegah kematian, kekambuhan penyakit, menghentikan laju penularan TB dan mencegah terjadinya resistensi kuman terhadap OAT ( Obat Anti Tuberkulosis ). Pengobatan TB paru akan berjalan efektif apabila penggunaannya sudah tepat sesuai dengan pedoman yang digunakan. Ketepatan penggunaan obat tercantum dalam Penggunaan Obat Rasional ( POR ) yang meliputi tepat indikasi, tepat pemilihan obat, tepat dosis, tepat lama pemberian, tepat diagnosis, tepat cara pemberian, tepat interval waktu, waspada efek samping, tepat pasien, tepat informasi, tepat tindak lanjut, tepat penyerahan obat dan kepatuhan pasien ( Kemenkes RI, 2011).Kesesuaian pengobatan Tb paru sangat penting, termasuk dari segi ketepatan indikasi, pasien, pemilihan obat, dosis dan lama pemberian OAT. Penggunaan obat dengan dosis yang sesuai akan memberikan efek yang maksimal pada pengobatan. Menurut Departemen Kesehatan Republik Indonesia dalam Pharmaceutical Care untuk Penyakit Tuberkulosis menyatakan bahwa untuk memperoleh efektifitas pengobatan salah satu prinsip yang digunakan yaitu pemberian OAT dalam bentuk kombinasi dari beberapa jenis obat (OAT FDC) (Depkes RI, 2005).

Melalui pemantauan penggunaan Obat Anti Tuberkulosis di Puskesmas Pangkalan Susu dan proses evaluasi pengobatan tuberkulosis paru maka dapat diketahui apakah kerasionalan terapi di Puskesmas Pangkalan Susu sudah tercapai atau belum. Atas semua dasar tersebut diatas, peneliti tertarik untuk melakukan penelitian terkait kerasionalan penggunaan Obat Anti Tuberkulosis (OAT) pada pasien penyakit Tuberkulosis Paru di Puskesmas Pangkalan Susu.

\section{MetodePenelitian}

Jenis penelitian ini merupakan penelitian penelitian ini menggunakan metode kualitatif dengan cara pengambilan data pasien tuberkulosis paru yang ada di Puskesmas Pangkalan Susu tahun 2019.Teknik pengambilan sampel menggunakan Total sampling.Penelitian ini telah dilaksanakan dari Agustussampai dengan Oktober 2020 dengan data yang diambil yakni data pasien TB periode Januari-Desember 2019. Populasi dalam penelitian ini adalah semua pasien TB paru yang menjalani pengobatan di Puskesmas Pangkalan Susu selama periode Januari -Desember 2019 yaitu sebanyak 24 orangData yang diperoleh dianalisis dengan menyusun data yang diperoleh dilapangan dan kemudian ditarik kesimpulan. Data yang sudah diperoleh kemudian diolah menggunakan aplikasi Microsoft Excel dan hasilnya disajikan dalam bentuk tabel. 


\section{Hasil dan Pembahasan}

Tabel 1. Karakteristik pasien TB Paru berdasarkan jenis kelamin di Puskesmas Pangkalan Susu

\begin{tabular}{llcccc}
\hline No & Karakteristik & Variasi & $\begin{array}{c}\text { Frekuensi } \\
(\mathbf{n})\end{array}$ & Presentase (\%) & TOTAL \\
\hline Jenis & Perempuan & 11 & 45,83 & 24 \\
Kelamin & Laki-Laki & 13 & 54,17 & $(100 \%)$ \\
\hline
\end{tabular}

Berdasarkan tabel di atas bahwa dari hasil penelitian jumlah penderita berjenis kelamin laki-laki lebih banyak daripada perempuan. Hal ini terlihat dari presentase laki-laki $54,17 \%$ sedangkan perempuan $45,83 \%$. Presentase yang lebih besar tersebut kemungkinan dapat disebabkan karena adanya kebiasaan merokok dan minum alkohol pada laki-laki, sehingga dapat menyebabkan turunnya sistem pertahanan tubuh dan tubuh terinfeksi kuman TB (Elisa dkk. Dalam Rahmawati, 2016).

Tabel 2. Karakteristik pasien TB Paru berdasarkan umurdi Puskesmas Pangkalan Susu

\begin{tabular}{ccccc}
\hline No Karakteristik & \multicolumn{1}{c}{ Variasi } & Frekuensi & Presentase \\
$(\mathbf{( n )})$ & Kelompok & 1 & $4,17 \%$ & TOTAL \\
\hline \multirow{2}{*}{ Umur } & $15-24$ tahun & 22 & $91,66 \%$ & 24 \\
& $25-64$ tahun & 1 & $4,17 \%$ & $(100 \%)$ \\
& 65 tahun keatas & & \\
\hline
\end{tabular}

Berdasarkan table di atas bahwa karakteristik pasien TB Paru berdasarkan umur digolongkan dalam 3 variasi kelompok, yaitu pasien rentang umur 15-24 tahun, pasien rentang umur 25-64 tahun, pasien diatas 65 tahun.

Tabel 3. Karakteristik pasien TB Paru berdasarkan penyakit penyerta yang diderita pasien di Puskesmas Pangkalan Susu

\begin{tabular}{lllccc}
\hline No & Karakteristik & \multicolumn{1}{c}{ Variasi } & $\begin{array}{c}\text { Frekuensi } \\
(\mathbf{n})\end{array}$ & $\begin{array}{c}\text { Presentase } \\
(\%)\end{array}$ & TOTAL \\
\hline & Kelompok & 18 & $75 \%$ & \\
\hline $\begin{array}{l}\text { Penyakit peyerta } \\
(\mathrm{PP})\end{array}$ & Dengan 1 PP & 6 & $25 \%$ & $(100 \%)$ \\
& $\begin{array}{l}\text { Dengan 2 atau } \\
\text { lebih PP }\end{array}$ & 0 & $0 \%$ & \\
\hline
\end{tabular}


Berdasarkan tabel di atas dapat dilihat bahwa pasien tanpa penyakit penyerta 18 orang ( $75 \%)$, pasien dengan satu penyakit penyerta sebanyak 6 orang $(25 \%)$ dan pasien dengan dua penyakit penyerta tidak ada $(0 \%)$. Penyakit penyerta pada pasien TB yang berjumlah 6 orang yaitu diabetes mellitus.Pada pasien diabetes mellitus respon imunologiknya menurun sehingga memudahkan berkembangnya penyakit infeksi termasuk Mycobacteriun Tuberculosis (Santos BR, 2013).

Tabel 4. Karakteristik pasien TB Paru berdasarkan tipe kasus diPuskesmas Pangkalan Susu

\begin{tabular}{|c|c|c|c|c|c|c|}
\hline No & Karakteristik & $\begin{array}{c}\text { Variasi } \\
\text { Kelompok }\end{array}$ & Frekuensi & (n) & $\begin{array}{c}\text { Presentase } \\
(\%)\end{array}$ & TOTAL \\
\hline & Tipe & Kasus baru & 24 & & $100 \%$ & 24 \\
\hline & Pasien & Kambuh & 0 & & $0 \%$ & $(100 \%)$ \\
\hline
\end{tabular}

Berdasarkan tabel di atas disimpulkan bahwa dari hasil penelitian mayoritas pasien yang berobat adalah pasien dengan kasus baru sebanyak 24 kasus (100\%).

Tabel 5. Pasien TB Paru berdasarkan diagnosis di Puskesmas Pangkalan Susu

\begin{tabular}{llcccc}
\hline \multirow{2}{*}{ No } & Karakteristik & Variasi & $\begin{array}{c}\text { Frekuensi } \\
(\mathbf{n})\end{array}$ & $\begin{array}{c}\text { Presentase } \\
(\boldsymbol{\%})\end{array}$ & TOTAL \\
& Kelompok & 24 & $45,28 \%$ & 53 \\
\hline \multirow{2}{*}{ Pasien yang } & Pasien Positif & 29 & $54,72 \%$ & $(100 \%)$ \\
\cline { 2 - 4 } & Pasien Negatif & & \\
\hline
\end{tabular}

Berdasarkan tabel 5 disimpulkan bahwa dari hasil pemeriksaan, 53 pasien yang diduga TB 24 orang $(45,28 \%)$ positif TB dan $29(54,72 \%)$ orang negatif. Penggunaan obat disebut rasional jika dengan diagnosis yang tepat. Jika diagnosis tidak ditegakkan dengan benar, maka pemilihan obat akan mengacu pada diagnosis yang keliru. Akibatnya obat yang diberikan tidak sesuai dengan indikasi yang seharusnya.

Tabel 6. Kesesuaian indikasi OAT yang diberikan pada pasien TB paru di Puskesmas Pangkalan Susu

\begin{tabular}{llcccc}
\hline No Status pasien & $\begin{array}{c}\text { Ketepatan } \\
\text { pemakaian } \\
\text { OAT }\end{array}$ & $\begin{array}{c}\text { Frekuensi } \\
(\mathbf{n})\end{array}$ & $\begin{array}{c}\text { Presentase } \\
(\%)\end{array}$ & TOTAL \\
\hline 1 & Pasien Baru & Kategori I & 24 & $100 \%$ & 24 \\
\hline 2 & Pasien Lama & Kategori II & 0 & $0 \%$ & $(100 \%)$ \\
\hline
\end{tabular}

Pada tabel diatas pada penelitian ini dapat dilihat bahwa pemakaian OAT pada pasien TB paru di puskesmas Pangkalan Susu semua memakai OAT Kategori I dan sudah sesuai 
indikasiTepat indikasi berkaitan dengan penentuan perlu tidaknya suatu obat diberikan pada kasus tertentu (Sastramiharja, 1997). Ketepatan ini dinilai dari hasil tes bacteriologis atau foto thorax. Pada penelitian ini di Puskesmas Pangkalan Susu suspek TB dinyatakan dengan hasil tes dahak. Bila hasil negative tetapi gejala menunjukkan ciri pasien TB, maka pasien harus menjalani foto thorax di rumah sakit rujukan.

Tabel 7. Data pasien TB Paru berdasarkan kategori pengobatan di Puskesmas Pangkalan Susu

\begin{tabular}{cccccc}
\hline \multirow{2}{*}{ No } & Karakteristik & Variasi & $\begin{array}{c}\text { Frekuensi } \\
(\mathbf{n})\end{array}$ & Presentase (\%) & TOTAL \\
\hline \multirow{2}{*}{ Kategori } & Kategori I & 24 & $100 \%$ & 24 \\
\cline { 2 - 4 } & kengobatan & Kategori 2 & 0 & $0 \%$ & $(100 \%)$ \\
\hline
\end{tabular}

Berdasarkan tabel di atas terlihat bahwa semua pasien yang menjalani pengobatan menggunakan OAT kategori I sebanyak 24 orang (100\%).Tepat pemilihan obat berkaitan dengan pemilihan kelas terapi dan jenis obat berdasarkan pertimbangan dari segi manfaat, keamanan, harga dan mutu.Seabagai acuan pemilihan obat dapat didasarkan pada buku pedoman pengobatan tertentu (Sastramiharja, 1997 dalam Renatasari 2009).Ketepatan pemilihan obat dalam penelitian ini dilihat dari obat yang diresepkan dan riwayat pengobatan pasien TB, pada penelitian ini di Puskesmas Pangkalan Susu obat yang digunakan yaitu obat kombinasi dosis tetap atau OAT KDT. Keuntungan pemakaian OAT KDT dapat disesuaikan dengan berat badan, menurunkan resiko resistensi obat karena tidak menggunakan obat tunggal, dan jumlah kaplet yang diminum lebih sedikit daripada obat tunggal sehingga kepatuhan pasien meningkat (Kemenkes RI, 2011).

Tabel 8. Ketepatan dosis yang diberikan pada pasien TB paru di Puskesmas Pangkalan Susu

\begin{tabular}{llccc}
\hline No & Ketepatan & Frekuensi (n) & Presentase (\%) & TOTAL \\
\hline 1 & Sesuai & 24 & $100 \%$ & 24 \\
\hline 2 & Tidak sesuai & 0 & $0 \%$ & $(100 \%)$ \\
\hline
\end{tabular}

Berdasarkan tabel di atas terlihat bahwa pemakaian Obat Anti Tuberkulosis di Puskesmas Pangkalan Susu pada penelitian ini sudah tepat dosis.Penilaian ketepatan dosis pada penelitian ini mengacu pada pedoman pengobatan yaitu Permekes no.67 tahun 2016 tentang Penanggulangan Tuberkulosis. Dosis yang diberikan tergantung pada berat badan pasien yang bersangkutan baik dalam pengobatan kategori I maupun kategori II. Hasil penelitian di Puskesmas Pangkalan Susu menunjukkan bahwa dosis yang diberikan sudah sesuai dengan pedoman pengobatan. 
Tabel 9. Penggunaan OAT Paruberdasarkan lama pengobatan di Puskesmas Pangkalan Susu

\begin{tabular}{lllccc}
\hline \multirow{2}{*}{ No } & Karakteristik & \multicolumn{1}{c}{$\begin{array}{c}\text { Variasi } \\
\text { Kelompok }\end{array}$} & $\begin{array}{c}\text { Frekuensi } \\
(\mathbf{n})\end{array}$ & $\begin{array}{c}\text { Presentase } \\
(\boldsymbol{\%})\end{array}$ & TOTAL \\
\hline \multirow{2}{*}{$\begin{array}{l}\text { Lama } \\
\text { pengobatan }\end{array}$} & Tep bulan & 0 & $0 \%$ & 24 \\
\cline { 2 - 4 } & $>6$ bulan & 23 & $95,83 \%$ & $(100 \%)$ \\
\hline
\end{tabular}

Berdasarkan tabel di atas dapat dilihat bahwa pada penelitian ini pasien yang menjalani pengobatan kurang dari 6 bulan tidak ada, yang tepat mejalani pengobatan 6 bulan 23 orang $(95,83 \%)$ dan yang menjalani pengobatan lebih dari 6 bulan 1 orang $(4,17 \%)$ diulang dari awal karena pasien lupa minum obat.Obat Anti Tuberculosis Kombinasi Dosis Tetap (OAT KDT) disediakan dalam bentuk paket dengan tujuan memudahkan pemberian dan menjamin kelangsungan pengobatan sampai selesai. Satu paket untuk 1 pasien untuk 1 masa pengobatan. Masing - masing kategori memiliki dua tahapan yaitu tahap intensif dan tahap lanjutan. Hasil penelitian di Puskesmas Pangkalan Susu 23 orang $(95,83 \%)$ lama pemberian obat sudah sesuai dengan pedoman pengobatan dan 1 orang $(4,17 \%)$ tidak sesuai dengan lama pedoman pengobatan.

\section{Kesimpulan}

Berdasarkan penelitian yang dilakukan di Puskesmas Tangkahan Durian dapatdisimpulkan sebagai berikut : Pemakaian obat tuberculosis paru di Puskesmas Pangkalan Susu Kecamatan Pangkalan Susu Kabupaten Langkat Tahun 2019 sudah rasional dan pengambilan obat pasien tuberculosis paru di Puskesmas Pangkalan Susu sudah tepat waktu berdasarkan data lama pengobatan pasien sesuai lama pengobatan untuk pasien TB paru yaitu 6 bulan.

\section{Referensi}

Alawiyah, T.B. (2012). Evaluasi Penggunaan Obat Anti Tuberkulosisi Pada Pasien Rawat Jalan di RS “ $X$ ” Tahun 2010. Skirpsi. Surakarta Universitas Muhammadiyah Surakarta.

Brooks. GF Butel SJ.Morse AS. (2011).Medical Microbiology.International Edition22nd ed. McGraw-Hill, New York. CDC, 2016, Transmission and Pathogenesis of Tuberculosis, https://www.cdc.gov, 12 Oktober 2016.

Chatu, S. (2010). TheHands-on GuidetoClinical Pharmacology.UK,WileyBlackwell.

Crofton,J., Mitchison, D.A. (1948). Streptomycin ResistenceinPulmonary Tuberculosis, B. Med.J.

Direktorat bina farmasikomunitas dan klinik Direktorat jenderal Bina kefarmasian dan alat kesehatan departemen kesehatan RI. (2005). Pharmaceutical Care Untuk penyakit Tuberkulosis. 
Direktorat Bina Penggunaan Obat Rasional. (2008). Materi Pelatihan Peningkatan Pengetahuan dan Keterampilan Obat Bagi Kader.

Dinas Kesehatan Sumatera Utara. (2019). Profil Kesehatan Sumatera Utara, 2018

Dinkes Kabupaten Langkat. (2020). Profil Kesehatan Kabupaten Langkat Tahun 2019.

Infodatin (Pusat Data dan Informasi Kementerian Kesehatan RI). (2018). Tuberkulosis

Jawetz, et al. (2010). Mikrobiologi Kedokteran. Ed. 23. EGC, Jakarta.

Kemenkes RI. (2011). Pedoman nasional pengendalian tuberkulosis.

Kemenkes RI. (2014). Direktorat Jenderal Pengendalian Penyakit dan Penyehatan Lingkungan.Pedoman Nasional Pengendalian Tuberkulosis : Indonesia Bebas Tuberkulosis. Kementrian Kesehatan RI, Jakarta.

Kemenkes RI. (2018). Infodatin tuberkulosis

Konomi,N, Lebwohl, E.,Mowbray, K., et al. (2002). Fine Structures of Intracytoplasmic Organelles of Mycobacteria, J.Biophys.Cytol

Ma,Z. Ginsberg, A. M \& Spigelman. (2007). Antimycobacterium Agents, Global Alliance for TB Drug Development, New York, USA.

Narasimhan, P .Wood,J., RainaMacIntyre,J.\& Dilip M. (2013). Review Article: Risk Factorsfor Tuberculosis, Pulmonary Medicine, Article ID 828939,11 Pages

PDPI. Reviono. (2016). Pedoman tatalaksana infeksituberkulosis laten. Bagian Pulmonologi dan Kedokteran Respirasi FK UNSPDPI Cabang Surakarta

Peloquin, C., et al. (1999). Pharmacokinetics of Ethambutol under Fasting Conditions, with Food, and with Antasida,Antimicrob Agents Chemother.

Santos B.R, Locatelli R, Horta B.L et al. (2013). Socio-Demographic and Clinical Differences in Subject with Tuberculosis with and without Diabetes Melitus in Brazil.

Sastramiharja, S. (1997). Penggunaan Obat Yang Rasional Di Tempat Pelayanan Kesehatan, Majalah kedokteran Indonesia, Edisi 8, Jakarta.

Sensi,P. (1983). History of Development of Rifampin, Rev Infect Dis.

Syamsudin.Sesilian Andriani Keban. (2013). Buku Ajar Farmakoterapi Gangguan Saluran Pernapasan. Satelit Merdeka, Jakarta.

World Health Organization (WHO). (2002). Promoting Rational Use of Medicines : Care Components, Jeneva, World Health Organization.

World Health Organization (WHO). (2004). The Health Academy Avoiding Tuberculosis, Geneva, Switzerland

Zhang, Y.\& Mitchison,D. (2003). The Curious Characterisitics of Pyrazinamide: a Review, Int.J.Tuberc.Lung Disc.

Zumla, A, Nahid, P \& Cole, S.T. (2013). Advances in the Development of NewTuberculosisDrug And Treatment Regimens,Nat.Rev.Drug Discov. 